\title{
ENERGY OUTPUT ASSESSMENT OF LAFIA-OBI COAL IN A FLUIDIZED BED COMBUSTOR
}

\author{
E. 0 Ilyas $^{1}$, B. Z. Adewole, ${ }^{2,}$, S. A. Adio ${ }^{3}$, 0. T. Popoola ${ }^{4}$ and A. A. Asere ${ }^{5}$

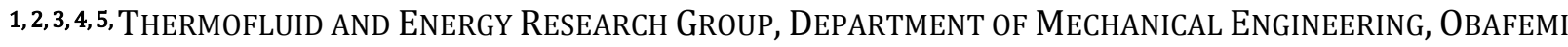 \\ AWOLOWO UNIVERSITY, ILE-IFE, OSUN STATE, NIGERIA. \\ E-mail addresses:1 kundayoseye2003@yahoo.com, ${ }^{2}$ bzadewole@oauife.edu.ng, \\ 3saheedadio@yahoo.com, ${ }^{4}$ bunmipopoola31@gmail.com 5 aaasere77@yahoo.co.uk
}

\begin{abstract}
This work investigated the energy output from the fluidized bed combustion of Lafia-Obi coal using five range of fuel equivalent diameters (FED) of $125 \mu \mathrm{m}, 250 \mu \mathrm{m}, 355 \mu \mathrm{m}, 2.5 \mathrm{~mm}$ and $5.0 \mathrm{~mm}$. Energy output in response to variation in bed temperature, FED, bed pressure, and fluidizing velocity was examined in the fluidized bed heat exchanger. Results indicated an increase in heat transfer rate by 80,11 and $25 \%$ when $5 \mathrm{~mm}$ coal was reduced to 355, 250 and $150 \mu \mathrm{m}$ respectively. Bed temperature increased by $8 \%$ for $355 \mu \mathrm{m}$ and decreased by $6 \%$ when $5.0 \mathrm{~mm}$ coal was fired. Higher bed pressure was observed when larger particle sizes $(5.0$ and $2.5 \mathrm{~mm}$ ) were fired. This resulted in poor bed temperature and increasing fluidization velocity and thus, reduced steam discharge temperature at the heat exchanger outlet.
\end{abstract}

Keywords: Lafia-Obi coal, energy output, fluidized bed, particle size, bed temperature, combustion efficiency

\section{INTRODUCTION}

Energy played a key role in the development and evolution of human society, and in alleviating world poverty $[3,13]$. In Nigeria, there is a growing energy demand (Figure 1) at an annual rate of $8.2 \%$. This demand has not been met by the installed production capacity since $1984[5,11]$. Nigeria holds a vast coal and sub-coal resources of approximately 2.5 billion metric tons in estimated reserve. The Nigerian government has recognized the need to revitalize the country's coal mining industry to provide fuel for power generation and domestic use. According to [15], the Kogi and the Benue (Orupka, Ezimo, Lafia-Obi) district can each support a coal-fired power plant with an ultimate capacity of approximately 3,500 MW. Further report [15] showed a good probability that these current reserves can support coal fired electrical generation in the range of 7,000 to 8,000 MW. Lafia-Obi coal deposit is found in the Middle Benue Trough. The deposit is estimated at 22.4 million tonnes with greater part still not fully explored [9]. Fluidized bed combustion, as a clean coal combustion process makes Nigeria's vast coal deposit a promising solution to the Nation's huge energy demand without further contamination of the biosphere. One of the major advantages of fluidized bed combustors is their efficiency for the combustion of wide varieties of fuel and fuel mixtures with very high combustion efficiency [7]. Other advantages include: high $\mathrm{SO}_{2}$ removal efficiency, low or no slagging of the boiler and low $\mathrm{NO}_{\mathrm{x}}$ generation. In addition, the turbulence in the bed results in good combustion [7].

The hydrodynamic condition and energy output of a fluidized bed combustion of fuels are influenced by certain parameters. These parameters include: fluidization velocity, bed temperature, bed pressure and fuel particle size [2]. Bed temperature is normally kept around $850^{\circ} \mathrm{C}$. Low temperature adversely affects the combustion as it decreases the combustion rate and increases combustion losses. High bed temperature causes high emissions of $\mathrm{NO}_{\mathrm{x}}$, high erosions due to ash deformation points and high thermal stresses on water tubes. In practical operations [7], bed pressure is an important parameter to monitor to reduce gas leakage from the furnace. The pressure drop across the bed and across the freeboard has been shown to influence bed hydrodynamic conditions [7]. The fluidization velocity controls the entire hydrodynamics of the bed including its heat transfer, entrainment of particles, defluidization, etc. 


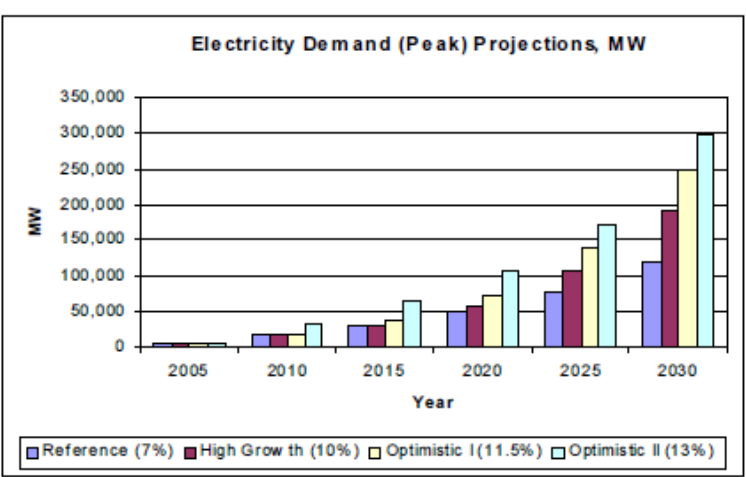

Figure 1: Electricity demand projection in Nigeria (Sambo, 2008)

Therefore, its value must be monitored and maintained carefully. Generally, the fluidization velocity has a typical value being in the range of 1 to $2 \mathrm{~m} / \mathrm{sec}$ for bubbling beds and 4-6 m/sec for circulating fluidized bed [7]. The particle size influences the bed hydrodynamics and combustion behavior to some extent, but exerts a dominant influence on heat transfer in the fluidized bed. The size distribution of the bed particles [2,7], is governed by the complex interaction of the following parameters: Size distribution of fuel ash particles as they enter through the feed; fluidizing velocity; attrition rate; feed system; bed drain rate; and entrainment rate. This work examines the correlation between fluidized bed parameters (coal particle size, bed Pressure and fluidizing velocity) and the energy output of Lafia-Obi coal combustion (heat transfer rate, bed temperature, combustion efficiency and heat exchanger steam outlet temperature). It also determined optimum coal particle size, pressure and velocity for maximum energy output.

\section{MATERIALS AND METHOD}

\subsection{Sample Preparation and Characterization}

Samples of Lafia-Obi coal was obtained from the coal field at Lafia- Obi Local Government area in Nasarawa State. About $3.7 \mathrm{~kg}$ coal sample was crushed using a hammer mill to obtain experimental samples. These samples were then subjected to cleaning to remove extraneous mineral matter and moisture in accordance with [16] and sieve analysis was carried out according to [6] in order to obtain five range of fuel equivalent diameters. Proximate analysis was carried out to determine the amount of moisture, volatile matter yield, ash yield, and fixed carbon of the coal sample in accordance with [16]. The ultimate analysis was carried out to determine the elemental composition of the coal samples using RBS (Rutherford Backscattering Spectrometric Technique). The calorific value test was performed to ascertain the energy content available in the raw fuel. This was done using XRY-1C bomb calorimeter in accordance with [17].

\subsection{Experimental Procedure}

The experiment was carried out in a fluidized bed combustor (Figure 2). The combustor bed inert material was $2.5 \mathrm{~mm}$ river sand. Coal particle sizes of $5.0 \mathrm{~mm}, 2.5 \mathrm{~mm}, 355 \mu \mathrm{m}, 250 \mu \mathrm{m}$ and $150 \mu \mathrm{m}$ sizes were prepared for combustion. Figure 3 shows different coal particle sizes used for the study. LPG was employed to start up the bed with the blower switched on to supply minimum air at $0.4 \mathrm{~m} / \mathrm{s}$ flow rate for combustion. This preheats the bed material to almost $550{ }^{\circ} \mathrm{C}$ (glow point of bituminous coal) before coal samples were injected. The first batch of fuel samples was the $5.0 \mathrm{~mm}$ that was fed to the bed at $200 \mathrm{~g} / \mathrm{min}$, to allow ample time for pyrolysis. Pressure probe connected to KANE 425 multimeter was inserted deep in the bed to monitor the bed pressure from 7-15 $\mathrm{Pa}$ in steps of $1 \mathrm{~Pa}$.

The valve beneath the bed was gradually opened to supply the combustion air at a fluidization velocity between 0.2 and $1.8 \mathrm{~m} / \mathrm{s}$ in steps of $0.2 \mathrm{~m} / \mathrm{s}$. The heat exchanger in the fluidized bed was filled with water at a constant flow rate of $1.92 \mathrm{E}-5 \mathrm{~m}^{3} / \mathrm{s}$ to about $20 \%$ of its volume to allow enough space for transformation of water to steam. The inlet water temperature and steam outlet temperature were monitored and recorded. Temperature profile along the bed height and combustion efficiency were determined.

\subsection{Theoretical Analysis}

The total heat output transfer tube by Newton's law is written as:

$$
Q_{\text {tot }}=\propto_{\text {Tot }} A_{t}\left(T_{\max }-T_{\text {in }}\right)
$$

where $Q_{\text {tot }}$ is the total energy transfer during the process, $A_{t}$ is the cross section of the tube immersed in the fluidized bed, $\alpha_{\text {Tot }}$ is the total heat transfer coefficient for fuel particle in fluidized bed, $\mathrm{T}_{\max }$ is the maximum outlet steam temperature from the tube and $\mathrm{T}_{\text {in }}$ is the inlet water temperature to the tube. Energy transfer to the heat exchanger tube is given by Gel 'Perin equation [10] as;

$$
N u_{p, \max }=0.75 A r^{0.22}\left(1-\frac{D_{T}}{S_{h}}\right)^{0.14}
$$

where: $\mathrm{Nu}_{\mathrm{p}, \max }$ is the maximum Nusselt number for bed particle, $A_{r}$ is the Archimedes number base on the difference between particle and gas density, $D_{t}$ is the diameter of the tube immersed in the bed and $S_{h}$ is the horizontal pitch of the immersed tube. 


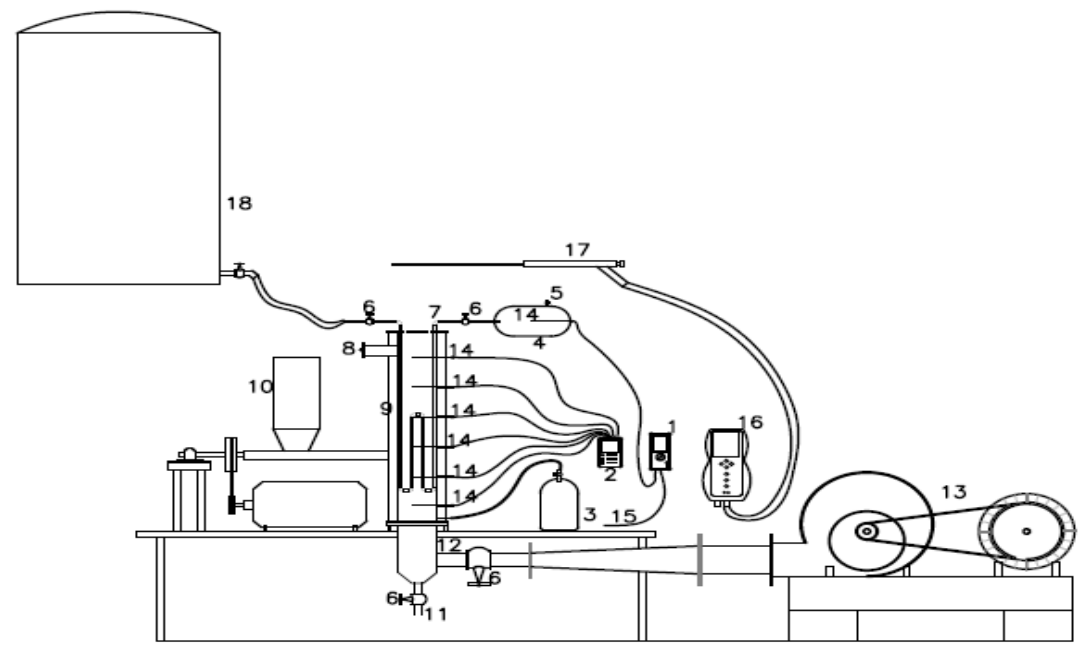

SCHEMATC ILLUSTRATION OF THE EXPERIMENTAL SET UP

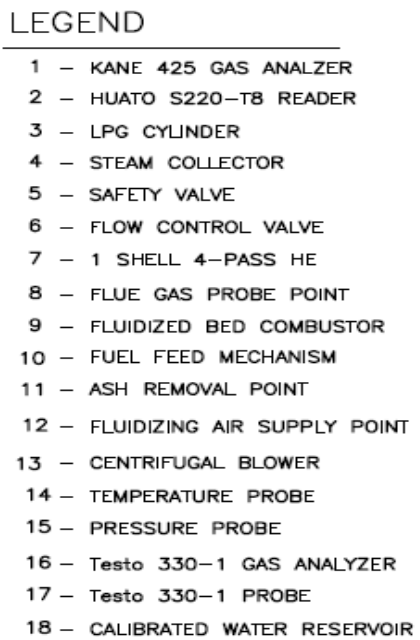

Figure 2: Set-up for the Experimental Procedure

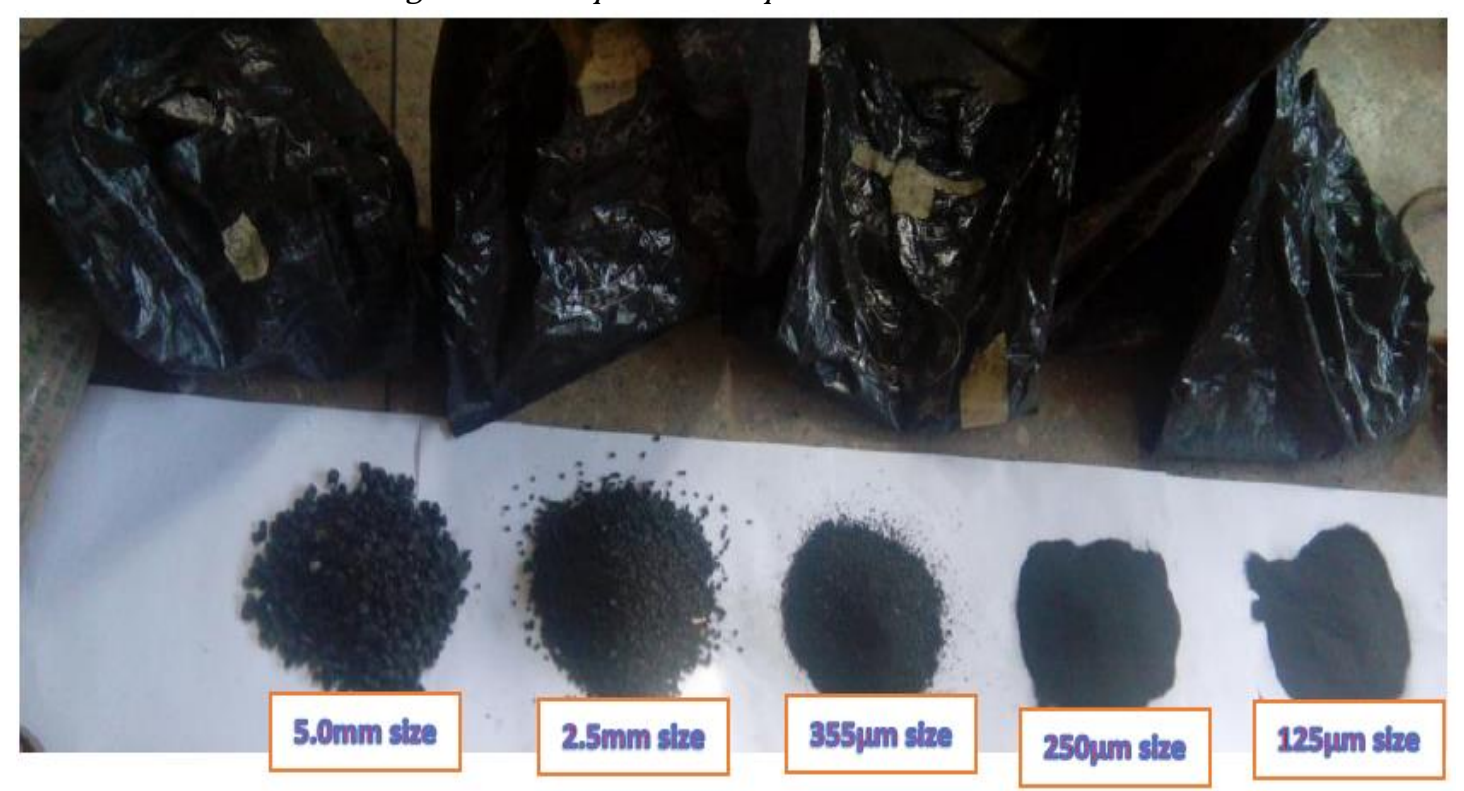

Figure 3: Coal particle sizes from sieve analysis

The Archimedes number is given as:

$$
A r=\frac{\operatorname{gd}_{\mathrm{p}}{ }^{3} \rho_{\mathrm{g}}\left(\rho_{\mathrm{p}}-\rho_{\mathrm{g}}\right)}{\mu_{\mathrm{g}}{ }^{3}}
$$

where $\mathrm{Ar}$ is the Archimedes number, $\mathrm{g}$ is the gravitational pull $\left(\mathrm{m} / \mathrm{s}^{2}\right), d_{\mathrm{p}}$ is the particle diameter of the fluidized bed material, $\rho_{\mathrm{g}}$ is the gas density $\left(\mathrm{kg} / \mathrm{m}^{3}\right)$, $\rho_{\mathrm{p}}$ is the density of inert bed material $\left(\mathrm{kg} / \mathrm{m}^{3}\right)$ and $\mu$ is the dynamic viscosity of the gas $(\mathrm{kg} / \mathrm{m} . \mathrm{s})$.

The Nusselt number is given as:

$$
N u=\frac{\propto d_{p}}{\lambda_{g}}
$$

where $\mathrm{Nu}$ is the Nussel number based on particle-gas temperature in the fluidized bed, $\alpha$ is the heat transfer coefficient for fuel particles in the fluidized bed and $K_{\mathrm{g}}$ is the thermal conductivity of the gas $(\mathrm{W} / \mathrm{mK})$

\section{RESULTS AND DISCUSSION}

\subsection{Proximate and Ultimate Analysis}

Table 1 shows the results for the proximate and ultimate analysis and the calorific value of Lafia-Obi coal. The results obtained for the moisture content, ash content, volatile matter, and fixed carbon were close to the value previously gotten by $[1,4$ and 8]. Approximately, Lafia-Obi coal has $2.16 \%$ moisture, $27.96 \%$ volatile matter, $17.94 \%$ ash and $48.76 \%$ fixed carbon. Ultimate analysis data indicated that the fuel contain high proportion of carbon $(72.12 \%)$ and oxygen (24.18\%). 
Table 1: Proximate and Ultimate Analysis of Lafia-Obi coal

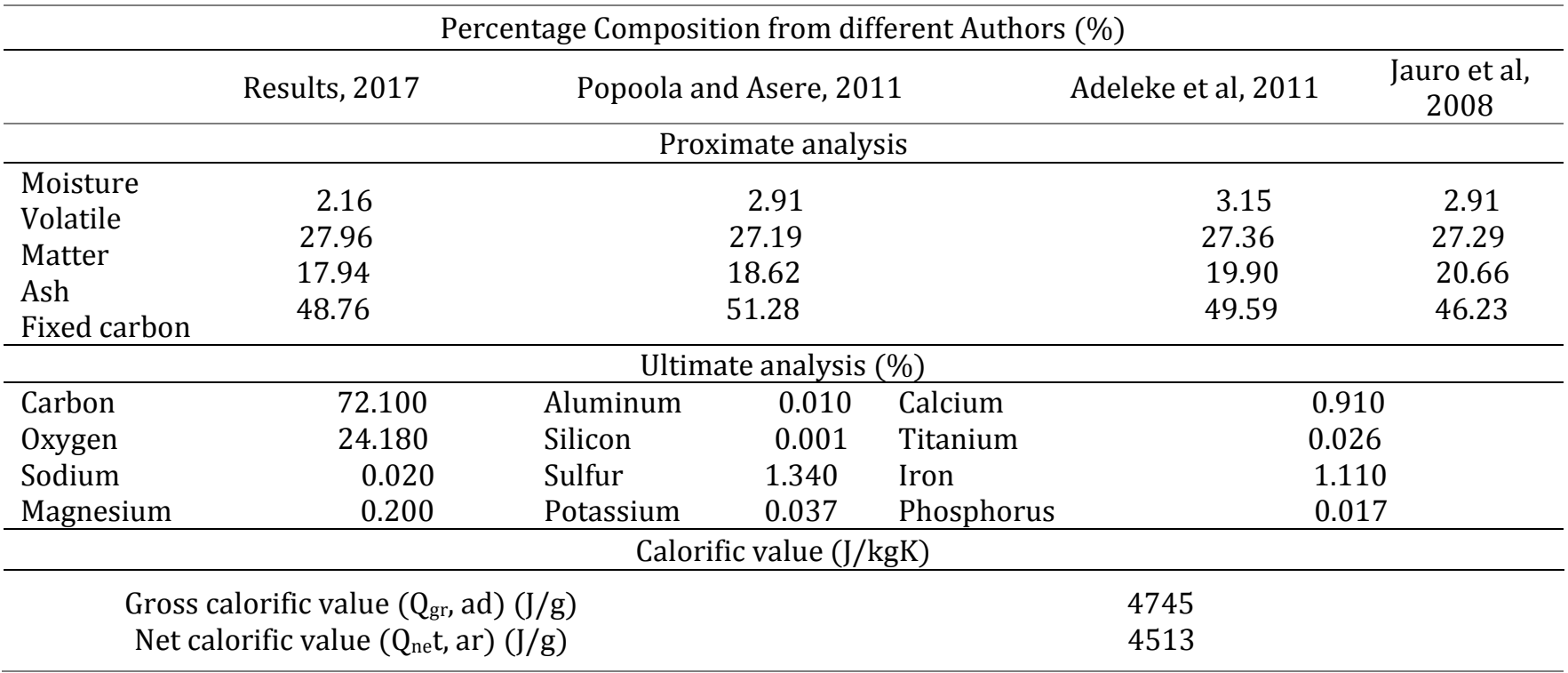

The fuel also contains low proportions of sulphur (1.34\%), iron (1.11\%) and calcium (0.91) while Sodium (0.020\%), Magnesium (0.2\%) Aluminum (0.01\%), Silicon (0.001\%), Phosphorus (0.017\%), Potassium (0.037\%) and Titanium (0.026\%) occur as trace elements. The results of the calorific value indicate that the energy content of Lafia-Obi coal ranges between $4,513 \mathrm{~J} / \mathrm{kgK}$ and 4,745 J/kgK.

\subsection{Effect of Coal Particle Size on Heat Transfer Rate}

Figure 4 shows the heat transfer coefficient as a function of the equivalent fuel particle diameter. As shown on the graph, a decrease in particle size from 5 $\mathrm{mm}$ to $2.5 \mathrm{~mm}$ gives an increase of $33 \%$ in heat transfer

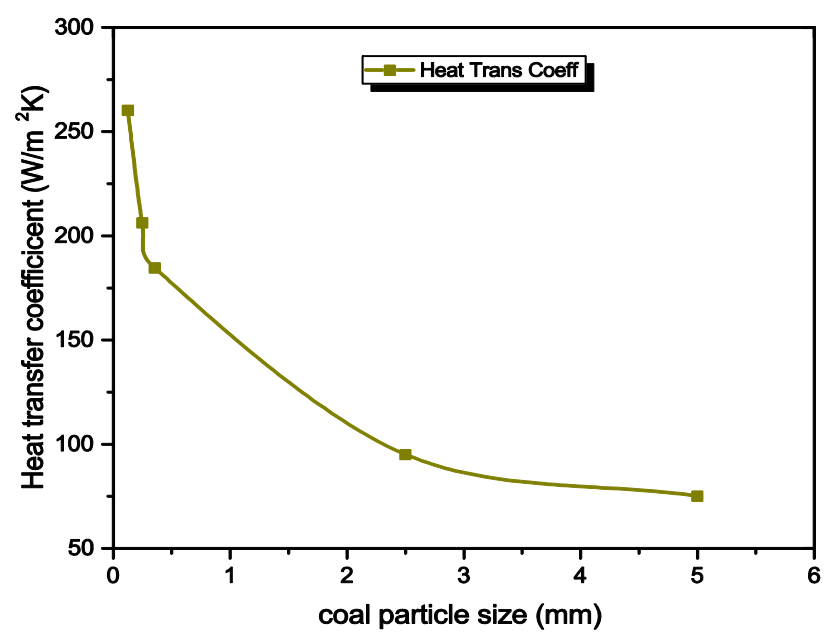

Figure 4: Effect of Particle equivalent diameter on Heat Transfer Coefficient coefficient. As the particle size decreased beyond 355 microns $(0.355 \mathrm{~mm})$ to $250(0.25 \mathrm{~mm})$ and 125 microns $(0.125 \mathrm{~mm})$, there was an increase of $11 \%$ and $25 \%$ respectively in heat transfer. Thus, the lower the particle size, the higher the heat transfer coefficient. The results here were similar to the ones obtained by [2]. The result here also indicates that the change in particle size from coarse to fine particles yields an increased heat transfer coefficient. This phenomenon could be due to an increased convection heat from small particle sizes of coal to the heat transfer tube [2, 7].

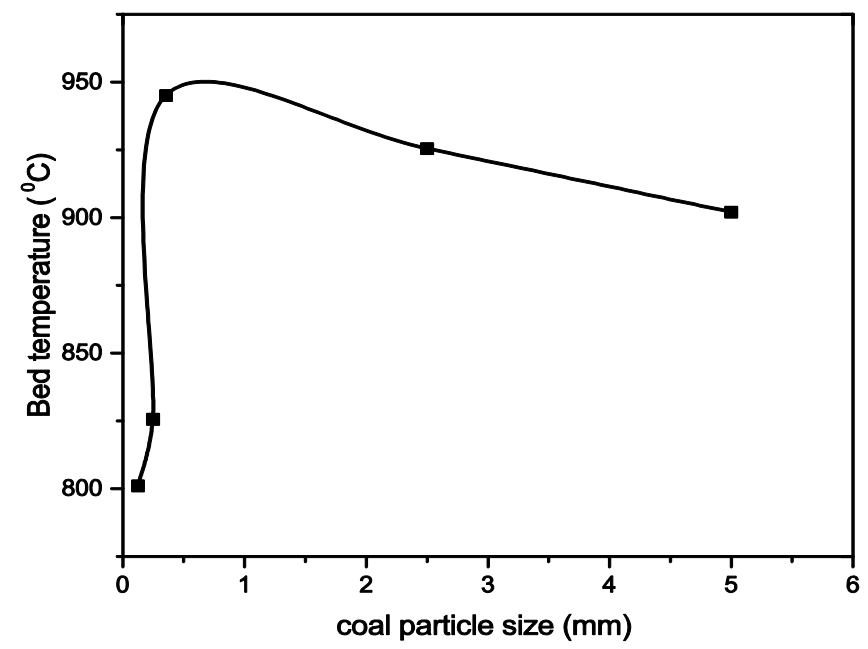

Figure 5: Effect of Particle equivalent diameter on Bed Temperature 


\subsection{Effect of Coal Particle Size on Bed Temperature}

Figure 5 shows the effect of particle equivalent diameter on bed temperature. A sharp increase was observed in bed temperature when coal particle size was increased from 125 microns $(0.125 \mathrm{~mm})$ to 355 microns $(0.355 \mathrm{~mm})$.

The small fine particles of coal (125 microns) was characterized with higher particle entrainment, short residence time, short burnout time and thus lower burning rate and lower bed temperature. As the particle size increased to 355 microns, the rate of fluidization increases and this enhanced the burning rate and hence, increased bed temperature. Further, a decrease in bed temperature was observed when coal particle size becomes higher. There was considerable decrease of 10 and $20 \%$ in the bed temperature as coal particle size increased from 355 microns to 2.5 and 5 $\mathrm{mm}$ respectively. This may be due to the decrease in the surface area of coal particles exposed to gas phase for oxidation [2] as the particles size becomes higher. Hence, it was observed that lower particle size of coal favours high bed temperature. The optimum bed temperature of $940{ }^{\circ} \mathrm{C}$ was observed for coal particle size of 355 microns.

\subsection{Effect of bed temperature on combustion efficiency}

Figure 6 shows the relationship between bed temperature and combustion efficiency for different coal particle size. The combustion efficiency was observed to increase with bed temperature for all coal particles sizes. The response to the combustion efficiency was observed to be more pronounced for the 355 and 250 micron sizes over wider temperature

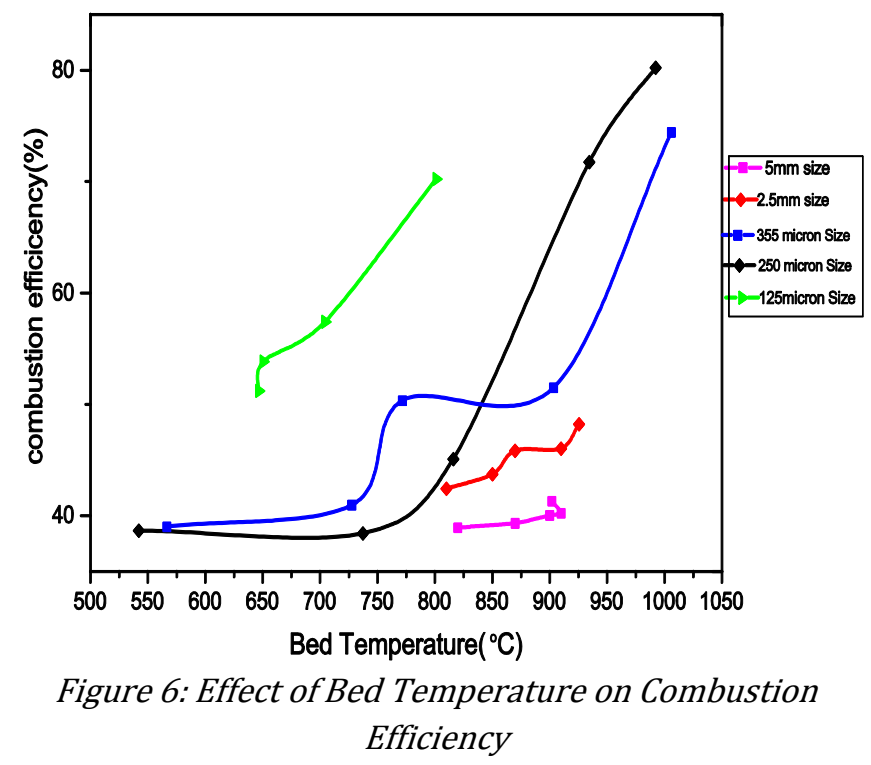

range of $562-970{ }^{\circ} \mathrm{C}$. The $5 \mathrm{~mm}$ and $2.5 \mathrm{~mm}$ coals sizes showed only a slight sensitivity to change in bed temperature. The observed change in bed temperature hardly show any effect on the combustion efficiency for $5 \mathrm{~mm}$ particle size within the tested temperature range from 820 to $850{ }^{\circ} \mathrm{C}$. This gave the lowest combustion efficiency of below $40 \%$. It was further observed that the combustion efficiency of larger coal particle size was very low for the temperature range of between $500-800^{\circ} \mathrm{C}$. At this temperature range, the combustion efficiency of $125 \mu \mathrm{m}$ is about $37 \%$ better than that of the larger coal sizes. The combustion of the smaller coal particles easily become kinetically controlled in the early part of its residency in the combustor while that of the larger coal only become kinetically controlled at the later part of their residency in the combustor. This view was given credence by [14]. This means that the energy that abounds in smaller size coal will be released much quickly in the combustion than it will be for the case of larger coal particles. The figure also shows that the energy released from the large coal particle of $5 \mathrm{~mm}$ is low even at bed temperature of 900 ${ }^{\circ} \mathrm{C}$.

\subsection{Effect of Exchanger Inlet Water Temperature on Outlet Discharge Temperature}

The heat exchanger outlet temperature increased astronomically for all particle sizes except for $5 \mathrm{~mm}$ coal size as shown in Figure 7. This trend is expected considering the combustion efficiency displayed earlier.

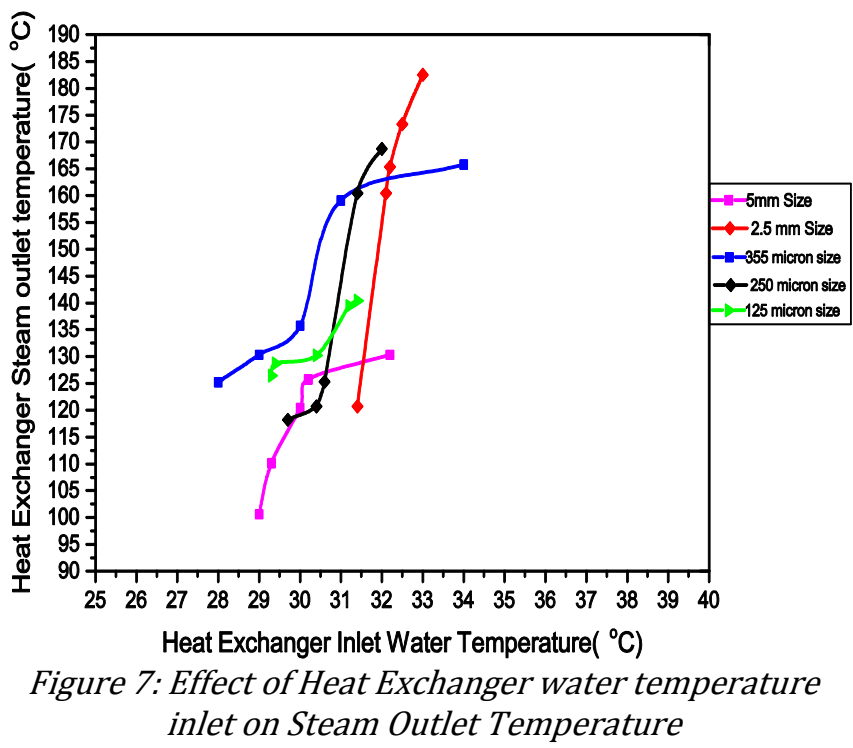




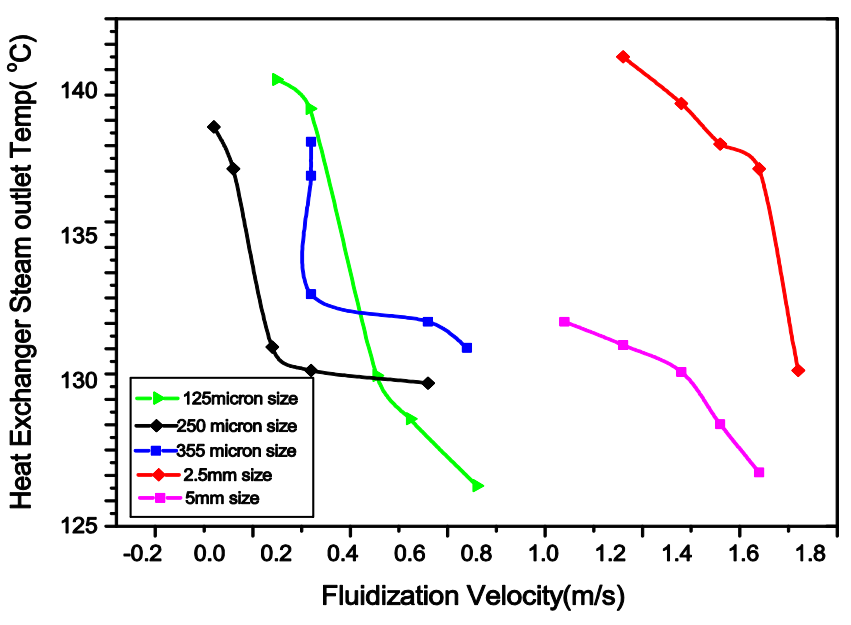

Figure 8: Effect of Fluidization velocity on Heat Exchanger steam temperature outlet

Of all the coal sizes, the energy discharge of the exchanger for $2.5 \mathrm{~mm}$ size coal was the highest i.e., the highest discharge steam temperature from the steam exchanger was $185^{\circ} \mathrm{C}$ which is quite appreciable while that of other coal sizes were below $176^{\circ} \mathrm{C}$.

\subsection{Effect of Fluidization Velocity on Exchanger Outlet Discharge Temperature}

The coal sizes produced a decrease in discharge outlet temperature at the heat exchanger as the fluidizing velocity increases (Figure 8). A higher bed voidage due to increased fluidizing velocity results in a lower concentration of bed particles around the heat exchanger tubes, and so, a shorter mean contact time between particles and tube wall. This resulted in lower particle convective heat transfer coefficient. Further, an increase in the bed voidage also results in lower particle densities in the bed section, causing a decrease in radiative heat transfer due to less radiating particles being present around the tube [14].

In summary, increasing fluidizing velocity leads to increase in bed voidage. This decreased heat transfer and thereby lower temperature of steam discharge at the exchanger outlet.

\subsection{Effect of Bed Pressure on Heat Exchanger Outlet Discharge Temperature}

Pressure changes occur as bed components transit through fixed bed, bubbling bed and turbulent bed due to air fluidization through the bed. In Figure 9, the heat exchanger steam outlet temperature increased with increasing bed pressure for all the particle sizes examined. In case of $5.0 \mathrm{~mm}$ coal particle, there was pressure interaction with the lowest steam outlet temperature of about $130{ }^{\circ} \mathrm{C} .5 .0 \mathrm{~mm}$ coal size fails to transit beyond bubbling fluidization regime. This

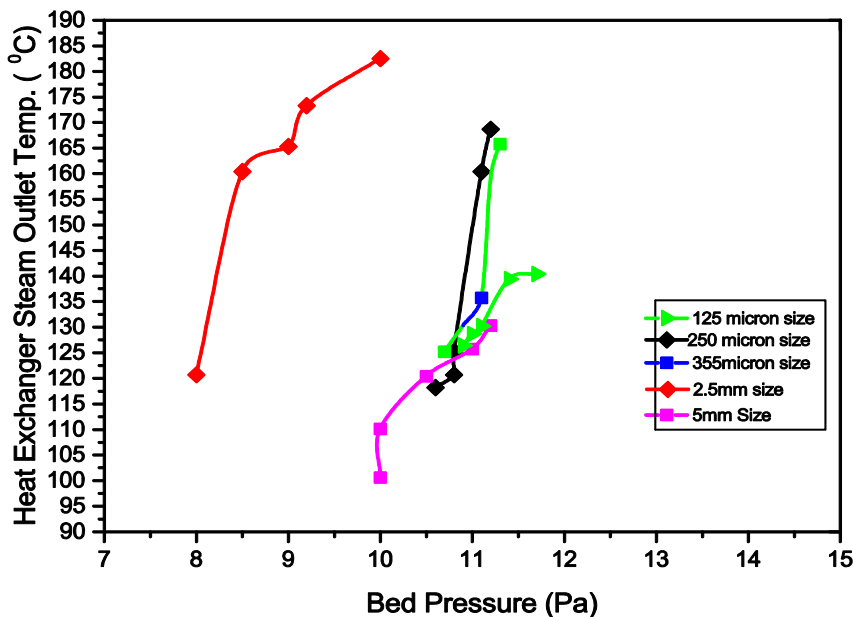

Figure 9: Effect of bed Pressure on Heat Exchanger Steam outlet temperature

resulted from higher voidage created by the particle and thus lowest pressure. This therefore caused low convective heat transfer to the heat exchanger leading to low steam temperature. In case of $2.5 \mathrm{~mm}, 355$ microns and 250-micron sizes, increased bed pressure resulted to higher bed expansion from intense mixture and chaotic movement of the fuel particles thus increasing the contact time with the heat exchanger thereby producing higher heat transfer rate and thus, higher steam outlet temperature.

\subsection{Effect of Bed Temperature on Heat Transfer Coefficient}

In Figure 10, heat transfer coefficient increases slightly with increasing bed temperature for 125, 250 and 355 microns coal sizes and seems to be constant at 60 and $100 \mathrm{~W} / \mathrm{m}^{2}$. $\mathrm{K}$ for 5 and $2.5 \mathrm{~mm}$ coal particles respectively, at bed temperature between 600 and 950 ${ }^{\circ} \mathrm{C}$. It is worthy of note that there is about $80 \%$ increase in heat transfer coefficient when the particle sizes changes from the mm-sized particle to micron-sized particles. This phenomenon is due to the increased oxygen diffusion into the smaller particle sizes of coal due to its large surface area. The increased oxygen diffusion enhanced the combustion rate of smaller coal particles, hence, resulted in higher temperature and higher heat generation. Further, the convective heat transfer coefficient increases due to higher particle breakage. The convective heat is more prevalent with smaller particle sizes than the higher particle sizes hence, heat transfer coefficients increases with increasing bed temperature for 125, 250 and 355 microns coal sizes with the highest value $\left(260 \mathrm{~W} / \mathrm{m}^{2} . \mathrm{K}\right)$ obtained for the smallest coal particle size (125 microns). 


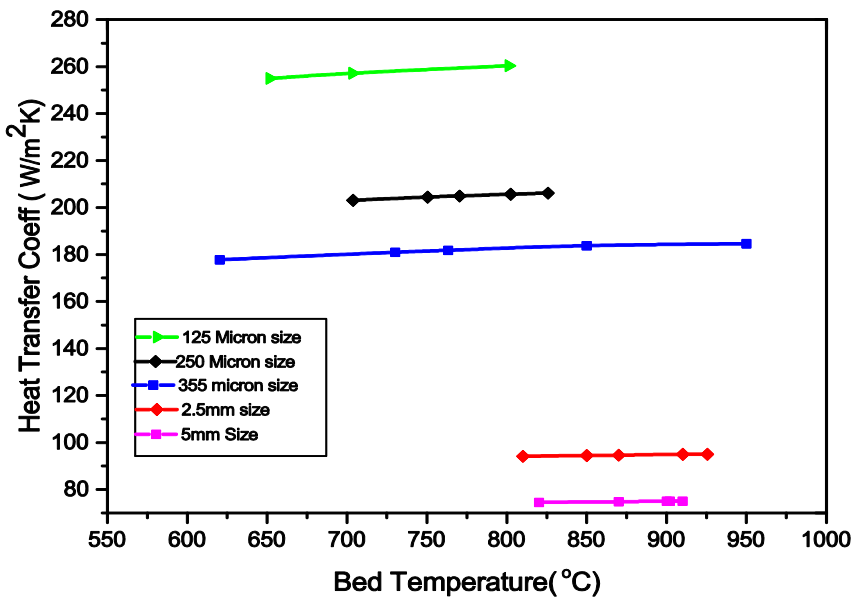

Figure 10: Effect of bed temperature on heat transfer coefficients for different particle equivalent diameter

\section{CONCLUSION}

This study confirmed an increase of about $78 \%$ in the energy output of Lafia-obi coal when coal particle size was changed from coarse particles to fine particles. Further, a change in fluidization velocity was observed to significantly affect the energy output of the fluidized bed combustor. This was evident by an increasing steam outlet temperature of the heat exchanger with the decreasing fluidization velocity. It was also observed from the study that fine particles have higher bed temperature and this enhanced energy output of Lafia-obi coal in the fluidized bed. The study concluded that the energy output from the combustion of coal in a fluidized bed depends on the fuel particle size, heat exchanger geometry and the temperature difference between the heat exchanger inlet and outlet water temperature. It is thus suggested from the study that the energy output of the system can be improved upon significantly if the temperature difference is kept at maximum by either preheating the inlet water close to its boiling point, using waste heat from the bed and the flue gas, or by minimizing heat loss from the bed.

\section{NOTATIONS}

$\mathrm{Q}_{\text {tot }}$ Total energy transfer during the process, J/kg K.

$A_{t}$ cross section of the tube immersed in the fluidized bed, mm

$\mathrm{T}_{\max }$ maximum outlet steam temperature from the tube, ${ }^{\circ} \mathrm{C}$

$\mathrm{T}_{\text {in }}$ Inlet water temperature to the tube, ${ }^{\circ} \mathrm{C}$

$\mathrm{Nu}_{\mathrm{p} \text {,max }}$ maximum Nusselt number for bed particle

$\mathrm{Ar} \quad$ Archimedes number base on difference between particle and gas density

$\mathrm{D}_{\mathrm{t}} \quad$ Diameter of the tube immersed in the bed, $\mathrm{mm}$
$\mathrm{S}_{\mathrm{h}} \quad$ Horizontal pitch of the immersed tube, $\mathrm{mm}$

g gravity $\left(\mathrm{m} / \mathrm{s}^{2}\right)$

$d_{p} \quad$ particle diameter of the fluidized bed material, $\mathrm{mm}$

$\rho_{g} \quad$ gas density, $\mathrm{kg} / \mathrm{m}^{3}$

$\rho_{\mathrm{p}} \quad$ density of inert bed material, $\mathrm{kg} / \mathrm{m}^{3}$

$\mathrm{Nu}$ Nusselt number for heat transfer between fuel particle and fluidized bed

$\alpha$

$\Lambda_{\mathrm{g}}$

$\mu$

heat transfer coefficient for fuel particle in fluidized bed, $\mathrm{W} / \mathrm{m}^{2} \cdot \mathrm{K}$

heat conductivity of the gas, $\mathrm{W} / \mathrm{m}$. K

dynamic viscosity of the gas, $\mathrm{kg} / \mathrm{m} . \mathrm{s}$

\section{REFERENCES}

[1] Adeleke, A. A, Ibitoye, A. A, Afonja, A. A and Chagga, M. M . Multistage caustic leaching deashing of Nigerian Lafia-obi coal. International Journal of Petroleum \& Coal 53 (4): 259-265, 2011.

[2] Adewole B. Z. and Asere, A. A.. Experimental Study on Bed-to-Tube Heat Transfer Coefficients in Fluidized Bed. Proceedings of the Faculty of Technology International conference, Obafemi Awolowo University, Ile-Ife, Nigeria, volume 6, pp. 58-64, 2017.

[3] Akorede, M. F., Ibrahim, O., Amuda, S. A., Otuoze, A. O. and Olufeagba, B. J.. Current status and outlook of renewable energy development in Nigeria. Nigerian Journal of Technology, Vol. 36, No. 1, pp. 196 - 212, 2017.

[4] Popoola, 0. T. and Asere, A. A. Emission and Combustion characteristics of Lafia-Obi coal in Fluidized Bed combustor. Advanced Materials Research, 824: 318-326, 2011.

[5] Akhator, E. P., Obanor, A. I., and Igbinomwanhia, D. I. Thermal analysis of a small scale solid waste-fired steam boiler for power generation in Benin city, Nigeria. Nigerian Journal of Technology, Vol. 35, No. 3, pp. 555 - 561, 2016.

[6] ASTM International.. Standard Test Method for performing the sieve analysis of coal and designating coal size. Retrieved May 12, 2014, from Annual Book of ASTM Standards D4749: http://www.astm.org, 1989.

[7] Basu, P. Combustion and Gasification in Fluidized $B e d$, Taylor and Francis Group, Abingdon, United Kingdom, Pp. 57-97, 208-332. 2006.

[8] Jauro, A., Agho, M. O., Abayeh, O. J., Obaje, N. G., and Abubakar, M. B. Studies and cooking properties of Lamza, Chikila and Lafia-Obi coals 
of the Benue trough. Nigerian Journal of Mining and Geology, 44: 11-19, 2008.

[9] Obaje, N. G.. Geology and mineral resources of Nigeria. Volume 120 of Lecture notes in earth sciences. London: Springer, 2009.

[10] Oka, S. O.: Fluidized Bed Combustion. Mercel Dekker Incorporation, New York, 2004.

[11] Sambo, A. S.. Matching Electricity Supply with demand in Nigeria: Assessed from www.iaee.org, 2008.

[12] Speight, J. G.. The Chemistry and Technology of Coal, Third Edition: CRC Press Taylor \& Francis Group, New York, 2013.

[13] Vaclav, S.. Science, Energy, Ethics and Civilization. International Journal of Science, 35:709-729, 2010.
[14] Valk, M. and Bijvoet, U.H.C.. Atmospheric Fluidized Bed coal Combustion: Research, Development and Application: Coal Science and Technology, 22: 1-47, 1995.

[15] Ministry of Mines and Steel Development. Coal Exploration and Power Generation Opportunities in Nigeria, Behre Dolbear and Company Inc., USA, 2005.

[16] ASTM D-3173. Standard Test Methods for Moisture in the Analysis of Sample of Coal and Coke.

[17] ISO 1928. Determination of Gross Calorific Value and Calculation of Net Calorific Value, 1928. 